UDC 631.531:633.85 «401»

(C) 2017

S. Kalenska, Corresponding Member of the National Academy of Sciences of Ukraine, Doctor of Agricultural Sciences

N. Novytska, Candidate of Agricultural Sciences

Yu. Stepanenko, T. Stoliarchuk, V. Taran, A. Ryzhenko, National University of Bioresources and Natural Resources of Ukraine

O. Yeremenko, Candidate of Agricultural Sciences

Tavriya State Agrotechnological University

\title{
LONGEVITY OF SEEDS OF OILY CROPS
}

The purpose. To determine longevity of seeds of oily crops at different temperature storage procedures and their damage. To determine intensity of seed's respiration and factors which cause damage. Methods. Relative, analytical, field and laboratory methods. Results. At storage of seeds of oily crops in conditions of stable low positive $\left(+5^{\circ} \mathrm{C}\right)$ or negative temperatures their longevity is preserved during the long period. At storage in conditions of variable temperatures «ex situ» the economic longevity of seeds is sweepingly lost (for $4-12$ months). On an instance of soya bean it is shown how at various aspects and extents of damage of seeds intensification of respiration may lead to a sweeping viability loss of seeds. At modelling harvesting of corn dependences between moisture of seeds and level of their damage are determined. Conclusions. Features of preservation of longevity of seeds of sunflower, grey mustard, oily flux are determined and proved at different temperature storage procedures. Negative influence isproved of damaging seeds of soya bean and corn on their longevity.

Key words: longevity of seeds, germination, damaging, respiration, sunflower, mustard, flux, soya bean, corn.

Seeds are the carrier of genetic information, the key to preservation of planet's biodiversity, food and energy security of mankind, economic efficiency of growing crops, export and import-oriented goods with a significant share in the world market [1,2]. At the expense of high quality seeds crops yield increases by $30-40 \%[3]$.

An urgent problem, both for production and for science, is longevity of seeds and factors that determine it. The longevity of seed is ability to maintain 
viability for a certain time, or it is the actual period life of seed. Conditionally classified "biological longevity" and "economic longevity" of seeds [1, 4]. Biological longevity of seeds is due to the biological characteristics of species - the period of time during which seed sample retains the germinative ability of at least one seed. Biological longevity of seeds is important in terms of preservation valuable collections of seeds for storage in genetic banks, storage facilities. The commercial longevity of seeds is the length of time during which seed retains the germinative ability that corresponds to the normative requirements for seeds [5].

Seeds differ in periods of "life expectancy" in genebanks storage or seed collections and to determine the effectiveness of their preservation and longevity, especially short-lived seeds, international standardized methods are used and new ones are developed which contribute to the quantitative preservation of seeds in the sample $[6,7,8,9]$. The International Botanical Gardens Council (BGCI) recommends low positive temperatures $+5 \mathrm{C}$ and a shallow freezing to $-20^{\circ} \mathrm{C}$ for storing seeds [10]. The efficiency of storage increases with using deep freezing technology in liquid nitrogen at a temperature 196 [11].

The seeds of different species of plants vary in terms of storage length, but nowadays there is not enough information about proven dependencies between conditions of formation, storage, chemical composition of seeds and seeds longevity $[12,13]$. Chemical composition and seed morphology are primarily a species and varietal trait, but are also determined by abiotic and biotic factors of its formation, which can cause changes that often exceed varietal values [1, 5, 14].

In Cambridge was conducted an experiment with 207 seed samples, which included 42 species from the USDA National Plant Germplasm System (NPGS) collection, which totals 42,000 samples from 276 species. Samples of seed collection from yield 1934 - 1975 during the laying had a high germination ability, which changed with a different rate of storage variability at +5 and $-18{ }^{\circ} \mathrm{C}$ [15]. "Short-lived" was seeds of the families Apiaceae and Brassicaceae, and "longlived" seeds of the families Malvaceae and Chenopodiaceae. 
Longevity of seeds is also determined by the place of origin. Seeds that originate from Europe tend to have a lower life expectancy than seeds of similar species from Asia and Australia [15].

The longevity of seeds is significantly conditioned by conditions of seeds formation on mother plants. For analysis of samples of soybean seeds, which was stored in the Bulgarian genetic bank for seeds for 34 years at a temperature $-18^{\circ}$ C, it was established that the viability of seeds varied and significantly depended on conditions of the years of formation or harvest year and term of storage longevity was determined after 11 years and 34 years of storage [16].

In living organisms there is a continuous set of chemical transformations - a metabolism that provides their vital functions. Metabolic processes in a living organism have a double orientation - anabolic (synthesis) and catabolic (splitting of synthesized substances) [1. 5]. During anabolism occurs energy absorption processes in mainly by reduction chemical processes, and oxidation chemical reactions occur during catabolism, process of energy separation takes place. Ratio between reactions of anabolism and catabolism determines the level of vital activity of organism and content of individual substances in different cells of the plant organism in a certain period of development.

Quality of seeds, in addition to the morphological characteristics, is characterized by amount, composition and properties of spare nutrients. The main components of seeds are proteins, carbohydrates, lipids (fats and fatty compounds), nucleic acids, minerals, water, and others. Seeds are conventionally divided into groups with high content: starch, protein or fat $[1,4,5]$. Actually, longevity of seeds is largely due to the ratio of these components in the seeds. According to protein content, legumes are almost in three times higher than cereals, amount of fat in cereals and legumes is approximately the same, and in seeds of oil crops it is 10 times larger. Leguminous plants, although rich in protein, but most of them contain carbohydrates, and in the seeds of oil crops content of carbohydrates is very low. Mineral substances are highest in the seeds of oil crops and the least - in cereals. The group of legumes differs in terms of fat content in the seeds, and only 
in the seeds of individual crops is deposited a lot of fat: soybeans - up to 20\%; white lupine - up to 14 ; Peanut - up to $50 \%$. Seeds vary in quantity and quality of fat $[4,17]$ (Table 1$)$.

Table 1.

Content of fatty acids in seeds (\% of total) [4]

\begin{tabular}{|l|c|c|c|c|c|}
\hline \multirow{2}{*}{ Acid } & \multicolumn{5}{|c|}{ Crop } \\
\cline { 2 - 6 } & Sunflower & Soybean & Linseed & Castor & Maize \\
\hline Palmitic & - & $2-7$ & $5-10$ & 3 & 10 \\
\hline Stearic & $8-10$ & $4-7$ & $5-10$ & 3 & 10 \\
\hline Oleic & $20-30$ & $32-36$ & $5-20$ & $3-9$ & $42-45$ \\
\hline Linoleic & 60 & $52-57$ & $25-59$ & $2-3$ & $40-50$ \\
\hline Linolenic & - & $2-7$ & - & - & - \\
\hline
\end{tabular}

In the seeds, fats are heterogeneous and consist of mixture different triglycerides and fatty acids - for the seeds of cultures, there is a certain composition and ratio of components, which is characterized by numerical indices - acid number, iodine number, number of saponification (Table 2).

Table 2.

Physical and mechanical indices of fats different cultures

\begin{tabular}{|l|c|c|c|c|c|}
\hline \multicolumn{1}{|c|}{ Crop } & $\begin{array}{c}\text { Fat } \\
\text { content,\% }\end{array}$ & $\begin{array}{c}\text { Saponification } \\
\text { number }\end{array}$ & $\begin{array}{c}\text { Iodine } \\
\text { number }\end{array}$ & $\begin{array}{c}\text { Acid } \\
\text { number }\end{array}$ & $\begin{array}{c}\text { Specific } \\
\text { mass }\end{array}$ \\
\hline Sunflower & $35-55$ & $185-194$ & $119-144$ & $0,3-2,2$ & $0,920-0,927$ \\
\hline Linseed & $32-40$ & $184-197$ & $169-192$ & $0,7-1,7$ & $0,930-0,935$ \\
\hline Maize & $17-$ & $188-193$ & $111-131$ & - & $0,920-0,928$ \\
\hline Soybean & $20-$ & $188-195$ & $114-138$ & 4,7 & $0,922-0,934$ \\
\hline Castor & $45-60$ & $175-187$ & $81-90$ & $0,2-1,1$ & $0,950-0,974$ \\
\hline
\end{tabular}

Saponification number characterizes the molecular weight of fatty acids, iodine number - the degree of unsaturation of acids, acid number - neutralization of free acids. There is a relationship between content of fatty acids and viability of 
seeds. Seeds which have more than $5 \%$ free fatty acids lose germination in longterm storage $[1,4,22]$.

It is much more difficult to storage seeds of oil crops than grains of cereals. Oil crops seeds are characterized by a high content of glycerides of highly unsaturated fatty acids (linoleic and linolenic), which are prone to the accumulation of toxic products due to peroxidation. In the lipid complex of seed, that is stored, take place fermentative processes - split of phospholipids, glycerides; at the same time there is accumulation of free fatty acids. Under the influence of air oxygen and enzyme lipoxygenase, they are oxidized to form peroxides, hydroperoxides and other oxidation products. This is due to the high content of fat in the seeds of oil crops that is not able to bind and retain moisture (like protein and starch), which leads to a large saturation by moisture in other seeds substances and uneven distribution. In general low humidity the moisture content in those parts of the seeds that contain proteins and carbohydrates can be high and higher than content of oil.

Since the seed material is stored for a long time, in order to preserve its crop qualities and yield properties, it is necessary to provide an effective system of its protection against adverse factors for the formation of the achene and storage of seeds.

Despite the fact that chemical composition of fatty acids and other components is characteristic for each culture, depending on climatic and weather conditions, technology of growing and storage conditions variation can be a quite significant $[14,18]$.

\section{CONDITIONS AND METHODS OF RESEARCH}

Quality of the seeds of oil crops was determined on basis of current international and state regulatory documents: DSTU and TU on raw materials, DSTU on methods of analysis, instructions on techno-chemical control [19, 20, 21, 23]. 
To establish longevity of seeds was used basic sunflower seeds, mustard, linseed and seeds of the first-generation sunflower hybrid. For accompanying researches - respiration of soybean seeds, maize seed traumatizing, chemical composition of seeds, was used crop seeds, grown in stationary and temporary field experiments of the Plant Department of the National University of Life and Environmental Sciences of Ukraine under the appropriate schemes. Experiments with different cultures were conducted during 2008-2017.

Laboratory studies for determination sowing quality and longevity of mustard seeds, were conducted in the Testing Laboratory of the State Inspection of Agriculture of Ukraine (2010-2012); linseed (2016-2017), soybean (2008 - 2016) and maize (2015 - 2017 ) were carried out at the Laboratory of Seeds and seedlings quality Department of Plant Growing National University of Life and Environmental Sciences of Ukraine. Field and laboratory studies with sunflower (2014 - 2017) were conducted at the Taurian State Agrotechnological University.

Seed traumatizing was determined by indigo carmine solution dyeing $t$ [23] of two working seed samples of 100 pcs, separated from the seeds of the main culture. After 1-2 minutes solution was poured out, seeds were dried on a filter paper and in each sample macrotraumas of seeds were counted by naked eye and microtraumas of seeds with using magnifying glass.

Intensity of soybean seeds respiration was determined by respiratory indicator I.M. Tolmachov and titrated barium solution $\mathrm{Ba}(\mathrm{OH})_{2}$, which absorbs carbon dioxide released by seeds [24]. respiration intensity is determined by amount of carbon dioxide or absorbed oxygen in $\mathrm{ml}$ or $\mathrm{mg}$, released in these conditions by weight of seeds (100 or $1000 \mathrm{~g}$ of seeds on absolutely dry weight) in 24 hours. Respiration intensity of seeds was determined in the analytical biochemical Research Laboratory "Physiological bases of plant productivity" of the NSC "Institute of Biology" of the Kyiv National University name Taras Shevchenko. In the studies, whole and traumatized seeds of soybean varieties Annushka and Elena were grown in the field experiments of the Plant Growing Department at the PE "Agronomic Research Station" NULES of Ukraine. 


\section{RESULTS AND DISCUSSION}

Formed under favorable conditions sunflower seeds contain a whole range of biologically active substances (phospholipids, vitamin E, carotenoids) that protect fats from re-oxidation. In conditions of global warming and climate irritation of Ukraine, the influence of adverse environmental factors on formation of an effective system of fats protection from peroxidation is increasing.

Collected basic sunflower seeds were put into storage with germinative ability: hybrid Persey - 88\% and variety Lakomka - 85\%. Normative requirements for germinative ability of sunflower seed of the hybrid first generation is $85 \%$; variety - 87 - 92\% depending on the category of seeds, moisture content of seeds $10 \%[20]$.

Period of post-harvest maturation sunflower seeds was manifested in increasing germinative ability of seeds and lasted in hybrid Persey 2-3 months, in variety Lakomka - 4-5 months (Table 3). After 7 months of storage in the laboratory conditions (ex sity), seed germination was lower than normative, that is to say, economic longevity of seeds for storage under variable temperature and humidity is only 7-8 months after harvesting. Compare to hybrid Persey seeds variety Lakomka germinative ability descend faster, due to the different chemical composition of seeds.

In order to establish dependence germination of mustard seeds on storage temperature, a laboratory test was conducted (Table 4). obtained experimental data suggest that storage in a stable low positive temperature $\left(+5^{0} \mathrm{C}\right)$ for 34 months, germination of mustard seeds variety Roksolana decreased by $7 \%$ and was $87 \%$, corresponding to the normative requirements of the state standard for germinative ability of seeds - 85 - 90\%, depending on seed category [20]. For 12 months from the beginning of storage, germination decreased by only 1\%; for the next 12 months - by 3\%; the next 10 months - by another $3 \%$. 
Properties of sunflower seeds, depending on term of storage at $+12^{\circ} \mathrm{C}$, seeds humidity $-10 \%$.

\begin{tabular}{|c|c|c|c|c|c|}
\hline \multirow[t]{3}{*}{ Year } & \multirow[t]{3}{*}{ Month } & \multicolumn{4}{|c|}{ Hybrid / variety } \\
\hline & & \multicolumn{2}{|c|}{ Persey } & \multicolumn{2}{|c|}{ Lakomka } \\
\hline & & $\begin{array}{c}\text { Germinative } \\
\text { energy,\% }\end{array}$ & $\begin{array}{c}\text { Germination, } \\
\%\end{array}$ & $\begin{array}{l}\text { Germinative } \\
\text { energy,\% }\end{array}$ & $\begin{array}{c}\text { Germination } \\
, \%\end{array}$ \\
\hline \multirow{3}{*}{2014} & October & 86 & 88 & 85 & 85 \\
\hline & November & 86 & 89 & 90 & 93 \\
\hline & December & 98 & 99 & 91 & 93 \\
\hline \multirow[t]{7}{*}{2015} & January & 95 & 98 & 93 & 95 \\
\hline & February & 94 & 97 & 95 & 99 \\
\hline & March & 90 & 93 & 89 & 94 \\
\hline & April & 89 & 92 & 90 & 94 \\
\hline & October & 86 & 91 & 82 & 84 \\
\hline & November & 83 & 90 & 78 & 80 \\
\hline & December & 82 & 84 & 72 & 79 \\
\hline \multirow[t]{4}{*}{2016} & January & 81 & 83 & 70 & 72 \\
\hline & February & 79 & 81 & 68 & 68 \\
\hline & March & 75 & 80 & 61 & 63 \\
\hline & April & 74 & 73 & 60 & 62 \\
\hline
\end{tabular}

Changing the temperature regime of storage, which was in increasing temperature to $+12^{\circ} \mathrm{C}$, caused a significant decreasing of germination mustard seeds in a rather short period and the exit above standard requirements occurred after eight months of storage. Germination of mustard seeds after 12 months of storage at temperature $+12{ }^{\circ} \mathrm{C}$ decreased from $94 \%$ to $71 \%$; in 24 months - up to $34 \%$; 34 months - up to $1 \%$.

Mustard seeds storage in uncontrolled conditions (ex situ) or in conditions of production warehouses, germination of mustard seeds did not meet to regulatory requirements after four months of storage - 83\%, and until the next period of sowing, germination was only 33\% (05/24/2011).

Thus, economic longevity of mustard seeds for storage in warehouses without regulating temperature regime is only four months, and biological longevity is 16 months; at temperature $+12^{\circ} \mathrm{C}-8$ and 34 months, respectively. During the same seeds storage at a stable temperature $+5^{\circ} \mathrm{C}$ germination and 
germinative energy corresponds to the normative requirements and does not change much.

Table 4

Germinative energy and germination of mustard seeds variety "Roksolana" at different storage temperatures, $\%$

\begin{tabular}{|c|c|c|c|c|c|c|}
\hline \multirow{2}{*}{ Date } & \multicolumn{5}{|c|}{ Storage temperature } \\
\cline { 2 - 7 } & \multicolumn{2}{|c|}{$+5^{0} \mathrm{C}$} & \multicolumn{2}{c|}{$+12^{0} \mathrm{C}$} & \multicolumn{2}{c|}{ ex situ } \\
\cline { 2 - 7 } & GE & G & GE & G & GE & G \\
\hline 25.07 .2010 & 92 & 94 & 92 & 94 & 93 & 94 \\
\hline 25.09 .2010 & 92 & 93 & 90 & 91 & 87 & 89 \\
\hline 25.11 .2010 & 92 & 93 & 89 & 90 & 81 & 83 \\
\hline 23.01 .2011 & 91 & 93 & 89 & 89 & 74 & 75 \\
\hline 26.03 .2011 & 91 & 93 & 85 & 86 & 51 & 52 \\
\hline 24.05 .2011 & 92 & 93 & 76 & 78 & 27 & 33 \\
\hline 25.07 .2011 & 90 & 93 & 70 & 71 & 12 & 19 \\
\hline 28.09 .2011 & 91 & 92 & 62 & 66 & 3 & 8 \\
\hline 24.11 .2011 & 91 & 91 & 58 & 61 & 0 & 2 \\
\hline 25.01 .2012 & 91 & 91 & 53 & 53 & 0 & 0 \\
\hline 26.03 .2012 & 90 & 91 & 46 & 49 & 0 & 0 \\
\hline 24.05 .2012 & 89 & 91 & 40 & 42 & 0 & 0 \\
\hline 25.07 .2012 & 90 & 90 & 34 & 34 & 0 & 0 \\
\hline 27.09 .2012 & 89 & 90 & 23 & 26 & 0 & 0 \\
\hline 26.11 .2012 & 89 & 89 & 15 & 16 & 0 & 0 \\
\hline 25.01 .2013 & 87 & 88 & 8 & 10 & 0 & 0 \\
\hline 26.03 .2013 & 87 & 88 & 3 & 3 & 0 & 0 \\
\hline 27.05 .2013 & 85 & 87 & 0 & 1 & 0 & 0 \\
\hline
\end{tabular}

Note. GE - germinative energy; $G$ - germination

The same pattern was established for the storage of linseed seeds. Seeds of linseed varieties laid for storage at standard humidity and different air temperatures - unregulated conditions (ex situ), $+5^{\circ} \mathrm{C} ;-20{ }^{\circ} \mathrm{C}$ normative requirements for germination of linseed seeds make up $80-90 \%$ depending on the seed category, with a moisture content $12 \%$. The seeds were stored for 12 months. The initial germination of seeds corresponded to the normative requirements for linseed seeds. 
Storage of seeds at a temperature $-20^{\circ} \mathrm{C}$ ensured complete preservation of seeds germination throughout the all storage period; at temperature $+5^{\circ} \mathrm{C}$ - germination of seeds all varieties declined insignificantly - by 1-3\%, except the seeds of Liryna variety. Linseed storage in conditions "ex situ" led to loss of seeds germination significantly below the regulatory requirements and was - $11-75 \%$ in terms of varieties. Since the seeds are very hygroscopic, in storage without sealing, its humidity fluctuates with fluctuations in the humidity of the environment. The greater the fluctuations of equilibrium humidity, the more intense occurs metabolic processes in the seed, which, combined with high storage temperature, leads to decreasing seeds germination, and in the future to complete loss of ability to germinate. A significant range of variation of linseed varieties germination indicates needing for further research of determination factors that cause such a decrease in seeds germination.

Seeds longevity, in addition to genetic features of the species, is determined by quality of seeds formed by technological factors.

Seeds "life" duration depends essentially on traumatizing of seeds. Traumatizing of seeds can reach high rates, but it is often neglected, both in production and in scientific research [18]. Longevity of non-traumatized seeds is significantly higher than seeds with different types of injuries. One of indicators by which can determinate intensity of metabolic processes that occur in the seed is his breathing. Actually, intensity of respiration of seeds largely determines term of seeds storage. We conducted an experiment for determination characteristics of breathing seeds of two soybean varieties depending on traumatizing types, duration of seeds storage, physiological state of seeds - dormant and germination. Injured soybean seeds breathe much more intense than whole. Determination of respiration intensity whole dry seeds soybean varieties Annushka and Elena, showed, that seeds in the state of dormant absorb $1.91 \mathrm{ml}$ of oxygen / $100 \mathrm{~g}$ of dry matter per day; with Micro and Macro traumas of the shell - 2.31-2.63; with macrotraumas of cotyledons $-3,82$ - 4,01; with microtraumas of cotyledons, intensity of respiration increased to 6.63 and $7.91 \mathrm{ml}$ of oxygen / $100 \mathrm{~g}$ of dry matter per day, respectively, 
for seeds of Elena and Annushka varieties. Breathing intensity of soybean seeds depends both on the place of injury and on the damage degree. Seeds with microtraumas and macrotraumas of cotyledons breathe much more intensely. After seeds soaking for two hours, intensity of respiration increased by more than an order and consisted of the seeds variety Annushka - 41.2 - 64.8; Elena - 18.3 - 35.9 $\mathrm{ml}$ of oxygen / $100 \mathrm{~g}$ of dry matter per day in the presence of seed trauma, respectively for the whole seeds - 24, 2 and 14, $4 \mathrm{ml}$ of oxygen / $100 \mathrm{~g}$ of dry matter per day.

A day after seeds germination began, breathing intensity of the traumatized seeds increases, too, almost by an order of magnitude: variety Annushka increases to 175.3 - 476.5; Elena - 123.3 - $296.7 \mathrm{ml}$ of oxygen / $100 \mathrm{~g}$ of dry matter per day. We found that respiration intensity of the seeds for its germination increases significantly in seeds with micro and macro traumas, which causes a significant loss of energy and spare substances which necessary to form a full seedling.

After 20 months of storage, respiration intensity of dry soybean seeds increased in 1,1 - 1,4 times; seeds that were soaked in water for two hours - in 1,1 1,9 times; after sprouting in the course of one day in the period from 1.25 to 2.30 times, compare to the same samples that were analyzed before storage. The same pattern was observed with increasing respiration intensity depending on type of injury. Respiration intensity during storage increases both due to the activation of metabolic processes and activity of pathogenic microorganisms. Difference in respiration intensity of seeds may be related to both - morphology and chemical composition of seeds.

The main direction of seeds aging is opposite to its maturation: biochemical composition of grain changes, solubility of proteins decreases, amino acid composition of proteins gradually changes, and proportion of available lysine is reduced. These changes are especially noticeable in the first months of storage, as well as in grain drying. In fact, traumatizing of maize seeds is largely due to process of harvesting and heat-drying of grain. Due to this, it is important to choose hybrid, content of grains dry matter at the time of harvesting, the time of 
harvesting and the mode of drying the grain. Harvesting of grain with high humidity causes an increase in proportion of crushed grain and embryo injury. We conducted research about injury of maize hybrids seeds, which are belongs to the different groups of maturation, depending on moisture content in the grain at the time of harvesting. Maize hybrids Dniprovsky 257, Garant, Sensor were grown in a trifactorial experiment in the Kagarlytskyi district of Kyiv region, where, in addition to hybrids factor, effect of the factor "plant density" and the factor "norms of mineral fertilizers" was studied. For hand picking and grinding corn, seed injury was practically not observed - up to 5\%. Maize began to harvest by gathering in with combine harvester from the test sites at $40 \%$ humidity. Conducted studies allowed to establish that on average, decreasing in grain moisture content by $1 \%$ provide reducing traumas of grain by $1.5-3.0 \%$. With grain humidity above $40 \%$, share of beaten and injured seeds reached 10 - 60\%.

\section{CONCLUSIONS.}

Longevity of oil crops seeds is determined both by specific features and factors of growing, harvesting and storage of seeds.

It has been established that storage of oil crops seeds at stable low positive $\left(+5^{0} \mathrm{C}\right)$ or negative temperatures, longevity of seeds is maintained for a long period of time. With storage in "ex situ" variable temperatures economic longevity of seeds is lost in a very short period during 4- 12 months.

Period of post-harvest maturation of sunflower seeds appears in increasing seeds germination and lasts from 2-3 months (hybrid Persey) to - 4-5 months (variety Lakomka). Economic longevity of sunflower seeds in storage under variable temperature and air humidity (ex sity) is only 7-8 months after harvesting. Chemical composition of seed causes variability of seeds germination.

Economic longevity of mustard seeds for storage in warehouses without regulation of temperature regime (ex sity) lasts for four months, biological longevity is 16 months; at a temperature $+12^{\circ} \mathrm{C}-8$ and 34 months respectively; 
At $+5^{\circ} \mathrm{C}$, germination and seed germination energy decreased by only $7 \%$ in 34 months.

Storage of linseed varieties at a temperature $-20^{\circ} \mathrm{C}$ seeds germination, its economic and biological longevity does not change; $+5^{\circ} \mathrm{C}$ - seeds germination decreases insignificantly - by 1-3\%, except seeds of certain varieties; in conditions ext sity - germination of seeds was much lower than standard requirements and it was - $11-75 \%$ in terms of varieties.

Due to different types and degree of traumatization soybean seeds, intensification of respiration of seed occurs, which leads to a rapid loss of seeds viability. Seeds breathing grow considerably with micro and macro traumas as dry seeds and especially in the first microstates of its germination. Breathing intensity of soybean seeds is determined by place and degree of injury - seeds with micro and macro traumas of cotyledons breathe much more intense.

In model harvesting of maize relationship between moisture content in the seeds and level of traumatized seed has been established. Decreasing in the moisture content of grain at moment of harvest on $1 \%$ reduce seeds traumatization by $1.5-3.0 \%$. With grain humidity above $40 \%$, proportion of injured grain reached $10-60 \%$.

\section{Bibliography}

1. Shpaar D. Seeds and planting material / Shpaar D., Berezkin A., Ginapp K., Zakharenko A., Kalenskaya S. / M .: ID OOO "DLV Agrodelo", 2010. - V. 1. - $238 \mathrm{p}$.

2. Kalenska S.M. Global tendencies in development of seed industry// scientific works of the Southern branch National University of Life and Environmental Sciences of Ukraine "Crimean Agroecological University". Series: Agricultural Sciences 2008. - P. 26-32

3. Kalenskaya S.M. Seeds - basis of agrarian technologies / S.M. Kalenskaya, Z.D. Sych // Vegetable growing. №7. P.18-21.

4. Seed science and methods for determining quality of seeds agricultural crops / red. Kalenska S.M. / Kalenska S.M., Novytska N.V., Zhemojda V.L. etc. / Vinnytsya: FOP Danylyuk, 2011. - 320 p.

5. Plant Growing // Shevchuk O.Y., Kalenska S.M., Dmitryshak M.Y., Kozyar O.M., Demidas G.I. / K .: NAU, 2005. - 512 p. 
6. International rules for seed analysis / Volkodav V.V., Kalenska S.M., Novitska N.V., Beldiy N.M. / K., 2011. - 390 p.

7. FAO, Genebank standards for plant genetic resources for food and agriculture, Rome, 2014, Available at http://www.fao.org/3/a-i3704e.pdf.

8. Ripka Z. Seed Testing international / Z. Ripka// New method for germination of Brassica spp. and Sinapis alba seeds. 2009. - №137. P. 35-36.

9. Davies R.M., Newton R.J., Hay F.R. and Probert, R.J. 150-seed comparative longevity protocol - a reduced seed number screening method for identifying short-lived seed conservation collections // Seed Science and Technology. - 2016.- V. 44( 3). http://doi.org/10.15258/sst.2016.44.3.13

10. Botanic gardens and the world conservation strategy. London:Acad.Press, 1987.367p.

11. Leliberte B. Botanic garden seed banks: genebanks worldwide, their facilities, collections and network // Botanik Gardens Conservation News.1997.Vol.2. №7.P.18-22

12. Clarence R. Quick. How long can a seed remain alive? // Yearbook of Agriculture.- 1961.- P.95-99

13. Jones Q. , Earle F.R. Chemical analyses of seeds. II: Oil and protein content of 759 species. Economic Botany. 1966. - V.20, 127-155.

14. Kalenska S.M., Novitska N.V., Strihar A.E., Maleonchuk O.V., Antal T.V. Management by processes of formation high-quality seeds of agricultural crops // Scientific herald of NAU. - 2008. - V. 123.- P. 11-17

15. Longevity of seeds stored in a genebank: species characteristics // Walters C ., Lana M. ,Wheeler , Judith M. Grotenhuis. 2007. V.15. P. 1-20 DOI: https://doi.org/10.1079/SSR2004195

https://www.cambridge.org/core/journals/ seed-science- research/article/ longevity-of-seeds-stored-in-a-genebank-species- characteristics/ 5BADB40E9CE6B4E5AABBF 606E5D59491

16. Desheva G., Petrova S., Deshev M. Germinability of soybean seeds stored more than 30 years in the Bulgarian national seed genebank // World Scientific News. - V. 69. - 2017.- 29-46

17. Sendžikienė E., Makarevičienè V. Kalenska S. Exhaust emissions from the engine running on multicomponent fuel. Transport 2012; 27(2): ICID: 1033447 ICTM Value: 3.00. P. 111-117

18. Novitska N.V. Ways to reduce the negative effects of seeds traumatization // Scientific Bulletin NULES of Ukraine / Series «Agronomy» / K., 2012. Issue. 176. - p. 40-45.

19. Method of selection experiment (in plant growing) Teaching. manual / Ermantraut E.R., Gopcius T.I., Kalenska S.M., Krivoruchenko R.V., Tupchinova N.P., Prysiazhnyuk O.I.Harkiv: Publishing House of Kharkiv. nats agrar Un-ty name V.V. Dokuchaev 2014.229 p.

20. DSTU 2240-93 Seeds of agricultural crops. Varietal and sowing qualities / K: Derzhstandart of Ukraine, 1994. 73p 
21. DSTU 4138-2002. Seeds of agricultural crops. Methods for determining quality. - K .: Derzhspozhyvstandart of Ukraine, 2003. 173 p.

22. Shpaar D. Renewable plant resources / Shpaar D., Drager D., Kalenska S., Rakhmetov D. et al. St. Petersburg-Pushkin, 2006.V.1. 415p.

23. ISTA ( ed.) International Rules for Seed Testing. 2014

https://www.seedtest.org/upload/cms/user/Electronic_Rules_instructions.pdf

24. Plant physiology / redac. T.V. Parshikova Lutsk: Teren. 420p. 